\title{
Application of The Paikem Approach to Improve Vocabulary Material Learning Outcomes in SD Negeri 2 Karangwuni
}

\section{Eko Nuryanto}

SD Negeri 2 Karangwuni
nuryantoe85@gmail.com

\section{Article History}

accepted 14/11/2020

approved 21/11/2020

published 26/11/2020

\begin{abstract}
This study aims to increase understanding of vocabulary and their meanings by applying modeling techniques to grade II elementary school students. This study was designed in two cycles, with the research subjects of grade II students of SD N 2 Karangwuni in Pringsurat District, Temangggung Regency with a total number of students. 9 students. The research design used was the Classroom Action Research (PTK) spiral model from Kemmis and Taggart which included four stages of research, namely planning, implementing, observing, and reflecting. Students' understanding of the meaning of vocabulary has increased each cycle. Increased understanding of the meaning of students' vocabulary can be seen from the average cycle I only $66.6 \%$. While in cycle II the average score increased by $88.8 \%$. It was concluded that using the Paikem Approach which was carried out in accordance with the learning steps included the application of Active, Innovative, Creative, Effective, and Fun Learning, making learning conclusions, providing evaluation and closing the learning process in Indonesian subjects can improve student learning outcomes in grade 2 SD N 2 Karangwuni, Pringsurat District, Temanggung Regency Based on this research, teachers should be able to choose a learning model that is in accordance with the character of students, so that students are motivated to learn, so that students are able to understand subject matter and interesting.
\end{abstract}

Keywords: learning outcomes, Paikem's approach

\begin{abstract}
Abstrak
Penelitian ini bertujuan untuk meningkatkan pemahaman tentang kosakata dan maknanya dengan menerapkan teknik pemodelan pada siswa kelas II di Sekolah Dasar.Penelitian ini dirancang dalam dua siklus, dengan subjek penelitian siswa kelas II SD N 2 Karangwuni di Kecamatan Pringsurat Kabupaten Temangggung dengan jumlah siswa sebanyak 9 siswa. Desain penelitian yang digunakan adalah Penelitian Tindakan Kelas (PTK) model spiral dari Kemmis dan Taggart yang meliputi empat tahap penelitian yaitu perencanaan, pelaksanaan, pengamatan, dan refleksi. Pemahaman makna kosakata siswa mengalami peningkatan setiap siklusnya. Peningkatan pemahaman makna kosakata siswa dapat dilihat dari rata-rata siklus I hanya $66,6 \%$. Sementara pada siklus II perolehan nilai rata-rata meningkat $88,8 \%$.Disimpulkan bahwa dengan menggunakan Pendekatan Paikem yang dilaksanakan sesuai dengan langkahlangkah pembelajaran meliputi penerapan Pembelajaran Aktif, Inovatif, Kreatif, Efektif, dan Menyenangkan., membuat kesimpulan pembelajaran, memberikan evaluasi serta menutup proses pembelajaran pada mata pelajaran Bahasa Indonesia dapat meningkatkan hasil belajar siswa kelas 2 SD N 2 Karangwuni Kecamatan Pringsurat Kabupaten Temanggung Berdasarkan penelitian ini, hendaknya guru mampu memilih model pembelajaran yang sesuai dengan karakter siswa, agar siswa termotivasi untuk belajar, sehingga siswa mampu memahami materi pelajaran dan menarik.
\end{abstract}

Kata kunci: hasil belajar, Pendekatan Paikem

Social, Humanities, and Education Studies (SHEs): Conference Series https://jurnal.uns.ac.id/shes

p-ISSN 2620-9284

e-ISSN 2620-9292 


\section{PENDAHULUAN}

Hasil belajar Bahasa Indonesia di SD masih rendah, hal ini juga dapat dilihat pada hasil belajar Bahasa Indonesia Kompetensi Dasar pada siswa kelas II SD Negeri 2 Karangwuni Kecamatan Pringsurat pada semester 1 tahun ajaran 2020/2021 dengan jumlah siswa 9 dengan nilai rata-rata kelas 64,4 nilai tertinggi 100 nilai terendah 40. Berdasarkan hasil belajar Bahasa Indonesia tersebut dapat disimpulkan bahwa siswa yang bisa mencapai Kriteria Ketuntasan Minimal (KKM) 70 hanya 6 siswa dengan persentase $66,6 \%$ yang belum mencapai 3 siswa dengan persentase 33,3\% . Sedangkan nilai yang diharapkan adalah rata-rata 70 ke atas. Hal ini dapat ditemukan bahwa penyebabnya antara lain pembelajaran di SD Negeri 2 Karangwuni Kecamatan Pringsurat: (1) Guru masih menggunakan Model ceramah dan penugasan, (2) Media pembelajaran masih konvensional, dan (3) Motivasi dan aktivitas siswa masih rendah. Refleksi awal penyebab masalah itu didiskusikan bersama rekan-rekan guru di SD Negeri 2 Karangwuni Kecamatan Pringsurat dan hasilnya adalah menitik beratkan pada peningkatan aktivitas guru, aktivitas siswa dan hasil belajar. Aktivitas belajar yang rendah menyebabkan kurangnya pemahaman dalam penyerapan materi, dan kurangnya penyerapan berdampak pada rendahnya hasil belajar. Dari uraian kajian tersebut, maka peneliti merumuskan masalah Apakah media pembelajaran dengan berbantuan kartu kata dapat meningkatkan hasil belajar pada mata pelajaran Bahasa Indonesia pada siswa kelas II SD Negeri2 Karangwuni? Bagaimana peningkatan hasil belajar Bahasa Indonesia menggunakan Pendekatan paikem pada siswa kelas II SD Negeri 2 Karangwuni?

Sesuai dengan rumusan masalah di atas, penelitian ini bertujuan untuk: Meningkatkan hasil belajar melalui Pendekatan paikem pada siswa kelas II SD Negeri 2 Karangwuni Tahun Pelajaran 2020/2021. Mendiskripsikan arti kosakata melalui Pendekatan paikem di kelas II SD Negeri 2 Karangwuni Tahun Pelajaran 2020/2021. Maka diperlukan adanya perbaikan proses pembelajaran dalam aspek peningkatan motivasi siswa sehingga dari motivasi belajar yang tinggi, akan mempengaruhi prestasi belajar siswa. Alternatif dalam meningkatkan motivasi yang nantinya akan berdampak pada peningkatan prestasi belajar adalah merubah Model pembelajaran yang menitik beratkan pada aktivitas siswa sebagai subyek belajar, salah satu pemecahan permasalahan adalah penerapan Pendekatan paikem. Pendekatan paikem merupakan salah satu alternatif yang dapat diterapkan kepada siswa. Penerapan pendekatan ini dimulai dari merangsang siswa agar aktif,inovatif, kreatif supaya dalam kegiatan belajar mengajar siswa merasa senang. Salah satu keunggulan teknik ini adalah siswa mencari pengalaman dari lingkungan sekitar konsep atau topik dalam suasana yang menyenangkan. Penerapan Pendekatan paikem, diperoleh beberapa temuan bahwa Model ini dapat memupuk keaktifan dan kreatifitas siswa dalam mencari pengalaman baru mengenai kosakata, proses pembelajaran lebih menarik dan tampak sebagian besar siswa lebih antusias mengikuti proses pembelajaran, dan keaktifan siswa tampak sekali pada saat siswa mencari pasangan kartunya masing masing.

Hal ini sesuai dengan tuntutan kurikulum 2013 menghendaki kualitas pembelajaran yang dapat menjadikan sikap siswa kreatif, mandiri, kerja sama, solidaritas, kepemimpinan, empati, toleransi dan kecakapan hidup guna membentuk watak serta meningkatkan peradaban dan martabat bangsa. Berdasarkan uraian di atas Pendekatan paikem merupakan salah satu cara yang dapat meningkatkan prestasi belajar Bahasa Indonesia, maka peneliti memilih judul

Penerapan Pendekatan Paikem untuk meningkatakan hassil belajar Bahasa Indonesia materi kosakata pada siswa kelas II SD Negeri 2 Karangwuni Tahun Pelajaran 2020/2021. 


\section{METODE}

Penelitian Tindakan Kelas ini dilaksanakan di SD Negeri 2 Karangwuni Kecamatan Pringsurat Kabupaten Temanggung. Subjek penelitian adalah siswa kelas II pada semester I tahun pelajaran 2020/2021 dengan jumlah siswa 9 orang. Penelitian dilaksanakan SD Negeri 2 Karangwuni yang beralamat di Dusun Gedawung, Desa Karangwuni, Kecamatan Pringsurat, Kabupaten Temanggung. Waktu Pelaksanaan siklus 1 pada tanggal 16 November 2020 dan siklus 2 pada tanggal 23 November 2020. Berdasarkan prinsip-prinsip penelitian tindakan kelas dengan menggunakan siklus-siklus tindakan. Tindakan yang dilakukan sesuai dengan bahasan penelitian tindakan dengan menggunakan Pendekatan Paikem, dengan skenario kerja yaitu memberikan kepada siswa tentang penelitian yang akan dilakukan serta teman sejawat yang bertindak sebagai pengamat dalam penelitian yang meliputi : Memperbaiki pemahaman makna kosakata pada bidang studi bahasa Indonesia dengan menggunakan Pendekatan Paikem. Menjelaskan tugas-tugas yang harus diselesaikan oleh siswa pada setiap siklus. Memberikan arahan pada teman sejawat cara mengisi lembar observasi Menetapkan tugas masing-masing pada pengamat. Pada tahap ini dilakukan pengamatan berdasarkan skenario yang telah disiapkan dan peneliti mencatat semua yang terjadi agar memperoleh data yang akurat demi memperbaiki pada siklus selanjutnya. Untuk mengumpulkan data penulis menyiapkan: 1.Lembar observasi yang di gunakan untuk mencatat hasil pengamatan tentang perilaku siswa dalam keaktifan, menjelaskan, bertanya, menjawab pertanyaan memberi pendapat. 2 . Buku catatan harian yang di gunakan untuk mencatat semua tindakan belajar siswa seperti skors hasil belajar. Melakukan refleksi adalah mengingat, merenungkan, mencermati, sintesis, dan menganalisis kembali tindakan yang telah dilakukan sebagaimana yang telah di catat dalam observasi. Refleksi dalam penelitian tindakan kelas berusaha memahami proses masalah,persoalan dan kendala yang nyata dalam tindakan yang telah di lakukan selama proses pembelajaran.Agar refleksi di lakukan secara lebih bagus sebaiknya peneliti melakukan diskusi dengan pengamat melalui diskusi dengan pengamat dapat memberikan dasar bagi perbaikan rencana tindakan selanjutnya. Jika terdapat masalah dari proses refleksi, maka sudah seharusnya guru sebagai peneliti melakukan proses pengkajian ulang pada siklus berikutnya yang meliputi kegiatan rencana ulang, tindakan ulang dan observasi ulang sampai permasalahan tersebut dapat di atasi. Kriteria keberhasilan yang diterapkan berdasarkan model yang dilakukan melalui penelitian tindakan kelas dalam 2 siklus tindakan berhasil meningkatkan hasil belajar siswa dengan indikator keberhasilan sebagai berikut :

1 Siswa yang memperoleh nilai di atas KKM sebesar 88,8\% dari jumlah siswa

2 Kriteria Ketuntasan Minimal ( KKM ) yang ditetapkan pada mata pelajaran Bahasa Indonesia siswa mencapai nilai 70,

3 Adanya peningkatan Aktivitas yang terlihat dari hasil observasi

1. Penerapan Pendekatan Paikem

\section{HASIL DAN PEMBAHASAN}

PAIKEM merupakan sebuah tantangan bagi guru dan sekolah yang selama ini dianggap kurang dapat mengemas pembelajaran yang bermakna, berguna dan jauh dari tekanan. Guru profesional ditantang bagaimana mengelolah kelas dengan baik dan menciptakan suasana pembelajaran yang menyenangkan. Terwujud atau tidak PAIKEM dalam kelas diawali dari bagaimana guru dapat menata pembelajaran dengan baik. Harmonisasi pembelajaran dimulai dari kepiawaian guru sebagai pembangkit motivasi siswa, bagaimana memotivasi dan membangun serta menyelaraskan atau memperluas pengetahuan dasar yang dimiliki siswa, baik yang berkaitan 
dengan intlektualitas, personal, sosial, emosional dan kultural (Siregar, Wardani, \& Hatika, 2017)

Penerapan Pendekatan Paikem pada kompetensi dasar Menentukan makna kosakata dilaksanakan pada pembelajaran dalam setiap siklus, yaitu: siklus 1,dan siklus 2 diterapkan untuk pembelajaran materi makna kosakata. Dalam pembelajaran materi makna kosakata dengan Penerapan Pendekatan Paikem mengantarkan peserta didik semakin baik hasil belajarnya karena mudah, tidak meyulitkan, menyenangkan dan tidak membosankan peserta didik, sehingga mereka dapat merespon materi pembelajaran dengan baik dan dapat memenuhi tujuan pembelajaran.

2. Aktivitas Belajar.

Kegiatan pembelajaran yang dilaksanakan guru jugamasih bersifat teacher oriented, guru cenderung hanyamemberikan atau memindahkan informasi sebanyak-banyaknya kepada siswa, sedangkan siswa hanya mendengardan mencatat saja, membuat rangkuman materi, kemudianmengerjakan soal-soal pada LKS. Hal ini yang menyebabkan siswa menjadi pasif, tidak kreatif dan tidak inovatif dansangat merugikan siswa karena siswa hanya memperolehpengetahuan terbatas dari penjelasan guru dan materidibuku, siswa tidak dapat mengembangkan potensi di dalamdirinya sehingga hasil belajar yang dicapai tidak optimal (Marinta, Khutobah, \& Marjono, 2014). Model pembelajaran PAIKEM adalah model pembelajaran aktif, inovatif, kreatif, efektif,dan menyenangkan yang diberikan kepada siswa secara ptimal untuk mencapai tujuan pembelajaran dalam suasana yang tidak membosankan siswa.

Penerapan Pendekatan Paikem mengantarkan menjadikan aktivitas belajar peserta didik pada kompetensi dasar menentukan makna kosakata mengalami peningkatan. Hal ini dikarenakan ada beberapa faktor yang mempengaruhinya yaitu: a. Faktor Internal (yang berasal dari dalam) seperti: kesehatan, intelegensi dan bakat, minat dan motivasi, cara belajar serta pengetahuan tentang ilmu yang serumpun. b. Faktor Eksternal (yang berasal dari luar) yaitu: keluarga, sekolah, masyarakat dan lingkungan. Dengan Pendekatan Paikem hasil belajar peserta didik kelas II semester 1 SD Negeri 2 Karangwuni mengalami peningkatan, dari 9 siswa terdapat 8 siswa $(88,88 \%)$ mencapai ketuntasan belajar sedangkan yang belum tuntas 1 siswa (11,11\%). Dengan nilai tertinggi 100 dan nilai terendah 60 dengan rata-rata kelas 92 seperti pada tabel di bawah ini.

Tabel.1 Ketuntasan Belajar Hasil Tes Siklus I dan siklus II

\begin{tabular}{lccccc}
\hline \multirow{2}{*}{ No } & Ketuntasan & \multicolumn{4}{c}{ Jumlah Siswa } \\
\cline { 3 - 6 } Belajar & Siklus I & \multicolumn{3}{c}{ Siklus II } \\
\cline { 3 - 6 } & & $\begin{array}{l}\text { Jumlah } \\
\text { Persen }\end{array}$ & Persen & \multicolumn{2}{c}{ Jumlah } \\
\hline 1 & Tuntas & 6 & $66,66 \%$ & 8 & $88,88 \%$ \\
2 & Belum Tuntas & 3 & $33,33 \%$ & 1 & $11,11 \%$ \\
\hline & Jumlah & 9 & $100 \%$ & 9 & $100 \%$ \\
\hline
\end{tabular}




\section{SIMPULAN}

Dengan menggunakan Pendekatan Paikem Aktivitas belajar siswa dalam mata pelajaran Bhasa Indonesia kelas IV SD Negeri 2 Karangwuni meningkat.

Agar proses pembelajaran seperti ini dapat terus berlangsung dan hasil belajar peserta didik dapat terus meningkat, maka pihak sekolah dan pendidik perlu melakukan:

1. Pendidik selalu membantu dan memotivasi peserta didik untuk terbiasa membuat fariasi dan inofasi dalam pembelajaran, agar paserta didik tidak bosan dalam pembelajaran, dan timbul rasa senang serta percaya diri, juga tidak malu dan takut dalam berinteraksi dengan sesama peserta didik.

2. Pendidik harus memiliki sikap keterbukaan, kesediaan menerima kritik dan saran terhadap kelemahan-kelemahan dalam proses pembelajaran.

3. Pihak sekolah agar mendukung para pendidik untuk mengembangkan macammacam model pembelajaran dalam proses pembelajaran agar selalu ada peningkatan kualitas pembelajaran baik dalam proses maupun hasil belajar peserta didik.

\section{DAFTAR PUSTAKA}

Arikunto, S. 2008. Prosedur Penelitian Suatu Pendekatan Praktek. Jakarta : Rineka Cipta.

Djamarah, Syaiful Bahri. 2002. Strategi Belajar Mengajar. Jakarta: PT. Rineka Cipta.2006. Strategi Belajar Mengajar. Jakarta : Rineka Cipta.

Dimyati, Mudjiono, 2006. Belajar dan Pembelajaran. Jakarta : Rineka Cipta.

Hamalik, Oemar. 2010. Kurikulum dan Pembelajaran. Jakarta: Bumi Aksara

Kunandar. 2008. Langkah Mudah Penelitian Tindakan Kelas. Jakarta: PT. Rajagrafindo Persada.

Marinta, F. D., Khutobah, K., \& Marjono, M. (2014). Penerapan Model Pembelajaran Paikem Untuk Meningkatkan Aktivitas Dan Hasil Belajar Siswa Kelas Iv Bidang Studi Ips Pada Pokok Bahasan Jenis Dan Persebaran Sda Serta Pemanfaatannya Di Sdn Tempursari 01 tahun Pelajaran 2012/2013. Jurnal Edukasi, 1(1), 44-47. Retrieved from https://jurnal.unej.ac.id/index.php/JEUJ/article/view/1033

Rusman. 2011. Model-Model Pembelajaran (mengembangkan profesionalisme guru). Jakarta: PT.Rajagrafindo Persada.

Siregar, P. S., Wardani, L., \& Hatika, R. G. (2017). Penerapan Pendekatan Pembelajaran Aktif Inovatif Kreatif Efektif Dan Menyenangkan (Paikem) Pada Pembelajaran Matematika Kelas Iv Sd Negeri 010 Rambah. Jurnal Pemikiran Dan Pengembangan Sekolah Dasar (JP2SD), 5(2), 743. https://doi.org/10.22219/jp2sd.vol5.no2.743-749

Wardani I.G.A.K, Wihardit, K. dan Nasution, N. 2007. Penelitian Tindakan Kelas. Jakarta: Universitas Terbuka.

Wijaya, Dedi, 2009. Mengenal Penelitian Tindakan Kelas, Jakarta : Indeks. Zain, Asman. 2002. Strategi belajar Mengajar. Jakarta: Rineka Cipta. 